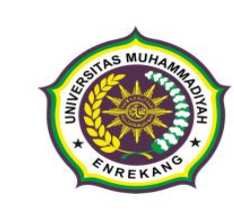

Vol. 5 - No. 1, year (2021), page 58 - 65

| ISSN 2548-8201 (Print)| 2580-0469) (Online)|

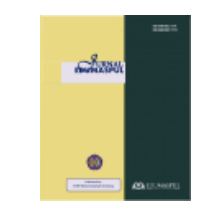

\title{
Optimalisasi Pembelajaran Akidah Akhlak Kelas IV melalui Pendekatan Inquiry- Discovery di Islamiyah Butoh
}

\author{
Imam Syafi' $i^{1 *}$ Alfi Elma Diana ${ }^{2}$, \\ 1,2 Universitas Islam Negeri Sunan Ampel Surabaya \\ * Corresponding Author. E-mail: imamsyafii.iwa@gmail.com
}

Receive: $12 / 02 / 2020$

Accepted: 28/02/2021

Published: 01/03/2021

\begin{abstract}
Abtrak
Pendidikan saat ini masih menjadi salah satu pokok bahasan yang sangat menarik untuk diperbincangkan, suatu pendidikan dapat dianggap berhasil apabila dapat mencetak generasigenerasi yang siap untuk terjun dan berkembang di masyarakat.Hal tersebut dapat diperoleh dengan memberikan pembelajaran yang tepat pada peserta didik, salah satunya dengan menggunakan pendekatan inquiry-discovery.Pembelajaran merupakan hal yang sangat penting untuk mempercepat pemahaman dan keterampilan peserta didik dalam hal ini diperlukan model pembelajaran yang tepat.Sejalan dengan itu, model pembelajaran discoveryinquiry merupakan model yang cocok diterapkan dalam pembelajaran di Madrasah Ibtidaiyah dengan tujuan terselenggaranya pembelajaran yang lebih optimal.Demi terciptanya karakter yang islami dan penuh sopan santun perlu ditanamkan pada diri anak yang dapat dimulai sejak dini yaitu dengan memberikan pemahaman mengenai akhlak melalui mata pelajaran Akidah Akhlah. Mata pelajaran Akidah Akhlak sendiri dapat diperoleh di sekolah-sekolah islam, salah satunya yaitu di Madrasah Ibtidaiyah.
\end{abstract}

Kata Kunci : Optimalisasi Pembelajaran, Pendekatan Inquiry-Discovery

\begin{abstract}
Education is currently still one of the most interesting topics to discuss, an education can be considered successful if it can produce generations that are ready to jump in and develop in society. This can be obtained by providing appropriate learning to students, one of which is by using the inquiry-discovery approach. Learning is very important to accelerate the understanding and skills of students, in this case an appropriate learning model is needed. In line with that, the discovery-inquiry learning model is a suitable model to be applied in learning at Madrasah Ibtidaiyah with the aim of implementing a more optimal learning. For the sake of creating Islamic character and full of courtesy, it is necessary to instill in children who can start early, namely by providing an understanding of morals through the Akidah Akhlah subject. The Akhlas subject itself can be obtained in Islamic schools, one of which is Madrasah Ibtidaiyah.
\end{abstract}

Keywords : Optimization of Learning, Inquiry-Discovery Approach 


\section{PENDAHULUAN}

Akhir-akhir ini pendidikan dasar memiliki peran yang sangat penting, kedudukanya sendiri dianggap sebagai landasan dasar dan utama yang berperan sebagai proses dimulainya perkembangan kemampuan dalam berfikir, akulturasi norma dan nilai kehidupan, serta keterampilan dalam hidup. Pendidikan dasar merupakan jenjang awal yang amat berpengaruh sebagai pondasi dasar sekaligus penting untuk dijadikan sebagai bekal dalam menentuhkan kemampampuan-kemampuan atau produktivitas generasi-generasi bangsa diperiode-periodemendatang.Pesatnya perkembangan bidang ilmu pengetahuan dan teknologi yang terus meningkat, berbagai informasi yang semakin mudah tersebar luas dan arus globalisasi yang memaksa dunia pendidikan untuk terus bersinergi dalam menata dan menentuhkan sistem yang tebaik bagi generasi bangsa sehingga mampu menghasilkan genrasi-generasi yang unggul dan mampu bersaing pada era ini. Pendidikan dasar yang termasuk didalamnya adalah Madrasah Ibtidaiyah termasuk bagian dari proses awal yang ikut andil dalam mempersiapkan generasi-generasi yang unggul dan kompeten di masa mendatang.

Pembelajaran menjadi salah satu hal yang sangat diutamakan dalam proses pendidikan. Melalui pembelajaran yang tepat, peserta didik dapat menangkap dan memahami setiap pelajaran yang disampaikan oleh pendidik.Pembelajaran sendiri harus dilakukan secara optimal, pengoptimalan pembelajaran bisa dilakukan dengan bebagai macam pendekatan pembelajaran, salah satunya yaitu dengan menggunakan pendekatan inquirydiscovery.Pendekatan ini bertujuan meningkatkan kemampuan berpikir kritis dan logis dalam memecahkan masalah, berpikir kreatif dan logis menunjukkan kemampuan berpikir kritis khususnya untuk Madrasah Ibtidaiyah/ sederajat masih rendah.

Upaya pengoptimalisasian proses belajar-mengajar perlu diadakannya suatu perencanaan yang matang mulai dari awal dimulainya rencana pembelajaran hingga evaluasi pembelajaran. Untuk menindak lanjuti hal tersebut seorang guru sangat dibutuhkan kemauan dan kemampuannya dalam mengupayakan optimalisasinya kegiatan pembelajaran.Seperti yang telah disebutkan dalam paragraph sebelumnya, bahwasanya pengoptimalisasian pembelajaran dapat dilakukan dengan menerapkan pendekatan inquiry-discovery. Pendekatan pembelajaran yang inquirydiscovery ini merupakan proses pembelajaran yang mana pendidik tidak secara langsung menyampaikan inti dari materi pembelajaran. Melainkan peserta didik diupayakan mampu untuk menganalisis suatu materi sehingga dirinya dapat memahami sendiri pokok pembahasan inti dari materi terebut.Macam pendekatan pembelajaran ini lebih memfokuskan terhadap penemuan suatu konsep yang mana sebelumnya belom pernah diketahui.

Dari beberapa pendapat terdahulu maka penulis akan mengkaji tentang:

1. Mengapa dalam pembelajaran Akidah Akhlak Kelas Empat di MI Islamiyah Butoh meggunakan pendekatan inquiry-discovery?

2. Bagaimana proses optimalisasi pembelajaran Akidah Akhlak Kelas Empat di MI Islamiyah Butoh melalui pendekatan inquirydiscovery?

Kemudian tujuan dari penelitian ini adalah untuk mengatahui alasan digunakannya pendekatan inquiry-discovery dalam pembelajaran Akidah Akhlak Kelas Empat di MI Islamiyah Butoh dan juga untuk mengtahui bagaimana proses optimalisasi pembelajaran. 


\section{METODE}

Jenis penelitian dalam pembuatan jurnal ini adalah dengan menggunakan penelitian pustaka serta pencarian dalam sebuah artikel , jurnal maupun buku serta cara menelaahnya atau mengambil benang merahnya dan membuat analisa pribadi. Dalam penelitian ini, peneliti melakukan penelitiannya secara analisis yang komprehensif mengenai persepsi-persepsi yang telah diungkapkan oleh orang-orang yang ahli dalam bidang keilmuan.Basis petunjuk atau data unggul penulis didaptkan dari jurnal, artikel maupun buku pustaka yang berhubungan dengan optimalisasi pembelajaran, pendekatan inquiry-dicovery, pembelajaran sekolah dasar dan juga Madrasah Ibtidaiyah.

Dalam penelitian ini penelitimengambil peran dalam proses yang tengah peneliti teliti. Dengan begitu diperlukan kedalaman analisi dari peneliti untuk hasil penelitian, sehingga penelitian ini menghasilkan suatu hasil yang bersifat subjektif yang tidak dapat digeneralisir (Kriyanto, 2014, p.50).Metode yang peneliti gunakan dalam penilitian ini adalah dengan metode observasi dan wawancara.

\section{HASIL DAN PEMBAHASAN}

\section{A. Optimalisasi Pembelajaran}

Optimalisasi memiliki kata asal optimal yang memiliki arti tertinggi, terbaik, sementara itu optimalisasi berarti suatu cara atau proses meningkatkan atau meninggikan pencapaian yang berasal dari tujuan awal dengan harapan agar terjadi kesesuaian macam-macam kriteria yang mana telah ditetapkan dari awal (Depdikbud, 1995, p.628).Optimalisasi dianggap sebagai suatu cara atau metode yang digunakan untuk penggalian suatu solusi secara matang sehingga dari beberapa solusi alternative dapat ditemukan solusi terbaik. Pemaksimalan optimalisasi ini dikerjakan secara maksimal terhadap suatu fungsi yang objektif dengan aturan tidak melakukan pelanggaran terhadap batasan yang telah ada.Efektivitas suatu sistem dapat meningkat sebab adanya optimalisasi, selaian itu dapat meminimalisir waktu proses, meningkatkan keuntungan, dan sebagainya. Dengan efektif dan efesien maka terwujudlah optimalisasi yang diharapkan.Hasil yang efektif dan efisien kemudian diarahkann kembali ke tujuan pengoptimalisasian.

Optimalisasi Pembelajaran sebagai upaya dalam perbaikan proses pembelajaran dengan maksud agar para siswa dapat memperoleh suatu keberhasilan baik keberhasilan dalam proses maupun terhadap hasil belajarnya. Perbaikan terhadap aspekaspek pembelajaran sebagai salah satu tujuan dari pengptimalisasian pembelajaran apabila masih didapati perbelajaran yang belom maksimal.Hal yang mendukung suatu keberhasilan dalam belajar, hal-hal yang menyebbabkan kegagalan sebagai bahan untuk mengajukan solusi alternative yang dimulai dari merancang dalam kegiatan tindak lanjut.Peserta didik yang dibantu oleh pendidik dalam kegiatan pembelajaran dapat terlihat dengan adanya upaya yang terencana, sistematik dan disengaja.

Ada beberapa factor yang mempengaruhi proses terjadinya optimalisasi pembelajaran, factor tersebut sepertipilihan guru terhadap pendekatan pembelajaran dan factor teknik atau metode. Agar peserta didik tidak merasa bosan ataupun jenuh dengan kegiatan pembelajaran, maka pendidik dapar memilih pendekatan maupun metode yang bermacam-macam yang dianggap sesuai dan cocok dengan kondisi peserta didik. Agar peserta didik merasakan dampak dari pembelajaran yang dilalui saling terkait dan memberikan manfaat bagi kehidupan seharihari, pendidik dapatmengkombinasikan antara kondisi lingkungan dengan materi 
yang terdapat dalam kurikulum. Pembelajaran partisipatif dalam proses pembelajaran, agar peserta didik merasa senang dan terlibat langsung dengan pendidik. Didalam menggali sekaligus mengembangkan potensi peserta didik, pendidik secara langsung dapat mendampingi peserta didik khususnya dalam pengembangan pembelajaran, dengan demikian peserta didik akan merasakan pembelajaran yang lebih bermakna (Sudjana, 2005, p.69). Proses ini meliputi kegiatan saling tukar pendapat dan pengalaman dalam memecahkan masalah atau membahas materi, membahas bahan belajar/ materi,menyiapkan alat bantu atau fasilitas pembelajaran, menerima informasi tentang materi/bahan belajar dan prosedur pembelajaran.

Dengan demikian dapat ditarik kesimpulan bahwa optimalisasi pembelajaran sebagai suatu metode atau caramemaksimalkan kegiatan peserta didik didalam pembelajaran, dengan catatan pendidik secara langsung terlibat dalam melakukan kegiatan pembelajaran dan berinteraksi secara langsung dengan peserta didik. Upaya pendidik dalam memaksimalkan/ mengoptimalkan pembelajaran dapat dilakukan melaluai berbagai ragam beragamcara, bebrapa diantaranya seperti berupa bimbingan belajar dan bantuan dorongan/motivasi. Dalam hal ini situasi kegiatan belajar sebagai penentu diterapkannya cara atau metode tersebut. Namun tujuan yang sesuai adalah pendidik tidak hanya berfokus pada mengajar saja akan tetapi juga mengharapkan agar peserta didik dapat secara aktif melaksanakan kegiatan pembelajaran.Sehingga factor utamanya disini adalah interaksi yang terjalin antara peserta didik dengan pendidik secara aktif.

\section{B. Pendekatan Inquiry-Discovery}

Demi tercapainya suatu tujuan intruksional didalam satuan tertentu instruksional, maka pendidik dan ppeserta didik dapat menggunakan alternative yang berupa pendekatan pembelajaran.Terpeliharanya suasana belajar yang menyenangkan, semakin mudahnya peserta didik dalam memahami materi yang disampaikan oleh pendidik, dan semakin mudah dan jelas pendidik dalam mengoptimalkan pelayanan pembelajaran karena adanya pendekatan pembelajaran inquiry-discovert (Sagala, 2010, p.68).

Pendekatan pembelajaran Inquiry ialah suatu pendekatan pembelajaran yang mana pendidik berperan sebagai fasilitator berwenang sebagai pendamping peserta didik dalam menemukan suatu permasalahan yang telah diberikan sebelumnya. Dengan demikian, dengan penerapan pendekatan inquiry-discovery ini pencarian dan penyelidikan terhadap suatu masalah dapat sekaligus peserta didik lakukan secara kritis, logis, dan sistematis.Penerapan pendekatan inquiry-discovery ditujukan untuk menumbuhkan keterampilan peserta didik dalam kegiatan penyusunan laporan (Dewi, 2017, p.108).

Tujuan lain dari pendekatan inquiry adalah untuk meletakkan dasar sekaligus mengembangkan cara berfikir ilmiah terhadaap diri peserta didik. Untuk itu peserta didik akan banyak yang menyibukkan diri untuk belajar sendiri dalam mengembangkan keterampilan untuk memecahkan suatu permasalahan. Dalam hal ini siswa benar-benar difokuskan sebagai subjek yang belajar(Dewi, 2017, p.168).Pendekatan pembelajaran Inquirysangan cocok dan sesuai jika diterapkan dalam proses pembelajaran sebab dengan pendekatan ini pemahaman siswa dapat tumbuh secara lebih baik. 
DiscoveryLearningmemusatkan pada belajar peserta didik sebagai aktifitas yang utama. Dalam menemukan suatu konsep dan dalil merupakan tuntutan bagi peserta didik dalam proses pembelajaran. Selain berkaitan dengan penemuan Mengajar dengan Discovery Learningjuga dapat membuat peserta didik semakin berfikir kreatif.Pendekatan pembelajaran discoverymelibatkan seluruh kreatifitas dan kemampuan peserta didik untuk dapat mencari dan menemukan sesuatu secara kritis dan sistematis. Pendekatan dengan model Discovery Learning sebagai salah satu cara atau strategi terpusatkan kepadapeserta didik, yang mana kelompokkelompok siswa dibawa kedalam suatu permasalahan untuk mencari jawaban tentang pertanyaan-pertanyaan yang telah termuat di dalam suatu prosedur danstruktur kelompok yang dijelaskan secara jelas (Mawardi, 2016, p.128).

Terdapat lima tahapan yang dapat ditempuh untuk melaksanakan pendekatan inquiry/ discovery yakni :
a. Perumusan masalah untuk dipecahkan siswa.
b. Menetapkan jawaban sementara atau lebih dikenal dengan istilah hipotesis
c. Siswa mencari informasi, data, dan fakta yang diperlukan untuk menjawab permasalahan/hipotesis.
d. Menarik kesimpulan jawaban atau generalisasi dalam situasi baru (Ahmatika, 2016, p.398).

\section{Optimalisasi Pembelajaran Akidah Akhlak Kelas 4 Melalui Pendekatan Inquiry-Discovery di Mi Islamiyah Butoh}

Salah satu tujuan endidikan Akidah Akhlak adalah untuk menumbuhkan dan meningkatkan keimanan yang terdapat di dalam diri peserta didik dengan harapan dapat diwujudkan kedalam bentuk akhlak sehari-hari secara terpuji dengan akhlak yang terpuji. Melalui penanaman dan pemupukan pengetahuan, pengalaman, pengamalan dan juga penghayatan terhadap diri peserta didik tentang akidah dan akhlak islam. Dengan demikian manusia dapat menjadi seorang muslim yang terus berkembang dengan meningkatkaan kualitas keimanan dan ketakwaan yang terdapat dalam dirinya kepada Allah SWT. sertamampu berakhlak mulia dan berperilaku terpuji dalam kehidupan pribadi, bermasyarakat, berbangsa dan bernegara (Azhar dan Izzah, 2017, p.78).

Pengimplementasian pembelajaran Akidah Akhlak dalam pendidikan diharapkan dapat membantu peserta didik dalam memahami materi Akidah Akhlak itu sendiri dengan maksud supaya peserta didi dapat mengimplementasikannya dalam kehidupan sehari-hari.Dalam hal ini diperlukan suaatu carayang tepat dalam proses pembelajaran agar materi Akidah Akhlak yang disampaikan oleh pendidik dapat dengan mudah dipahami oleh peserta didik. Cara tersebut dapat diterapkan dalam pembelajaran dan memegang peran yang utama atau penting dalam usaha meningkatkan efektivitas sehingga tercapainya suatu pembelajaran yang optimal.Pendekatan yang tepat juga dapat memberikan kemudahan untuk siswa dalam menyerap setiap materi yang disajikan.

Akidah Akhlak sebagai salah satu bagian dari mata pelajaran PAI yang telah ada mulai dari jenjang Madrasah Ibtidaiyah hingga Madrasah Aliyah.Di Madrasah Ibtidaiyah salah satunya di kelas empat mata pelajaran Akidah Akhlak sebagai mata pelajaran wajib, sehingga setiap peserta didik diharapkan mampu memahami mata pelajaran tersebut tidak terkecuali para peeserta didik di MI Islamiyah Butoh.Para pendidik telah 
melakukan berbagai pendekatan dan juga metode untuk memberikan pemahaman yang terbaik bagi para peserta didik, salah satunya yaitu melalui pendekatan inquirydiscovery.

Melalui pendekatan inquirydiscovery ini pendidik memberikan pemahaman sesuai dengan aturanaturan yang terdapat dalam pendekatan inquiry-discovery.Seorang pendidik selalu memiliki usaha lebih untuk bisa memberikan sebuah kesempatan kepada peserta didik agar dapat belajar melalui pemecahan atau penyelidikan terhadap suatu permasalahan.Layaknya problem solving, pemecahan masalah sebagai hal yang dipusatkan bagi peserta didik untuk mengasah keaktifannya melalui pendekatan inquiry secara mandiri.Peserta didik diberi peluang untuk mencari hingga menemukan sendiri solusi yang untuk memecahkan suatu permasalahan, dalam hal ini materi yang disajikan tidak dibahas sampai tuntas.Pondassi dasar pendekatan inquiry kuatnya ingatan peserta didik akan hasil belajar mereka melalui cara ini. Tidak hanya itu pendidikpun bisa lebih simple dan mudah dalam menyampaikan materi kepada peserta didik.

Peserta didik diberikan tugas mecari suatu permasalahan yang ada disekitar lingungannya, seperti ditemukannya sikap dermawan, rajin beribadah, sombong, dan sebagaianya yang kemudian peserta didik dapat mengelompokkan sikap-sikap tersebut kedalam perbuatan terpuji atau tercela. Setelah itu peserta didik dituntut mampu untuk membacaan hasil pekerjaanya di depan teman-temannya secara bergantian. Dengan demikian peserta didik dianggap telah sukses dalam memahami materi yang diberikan oleh guru mata pelajaran Akidah Akhlah secara kritis, dan mendetail.

Menurut Dra. Siti Rokhaniah, M.Pd.I selaku kepala Madrasah Ibtidaiyah Butoh penggunakan pendekatan inquiry-discovery pada mata pelajaran Akidah Akhlak kelas 4 ini menwajibkan keterlibatan aktif peserta didik yang terbukti dengan meningkatnya pemahaman, prestasi belajar, serta sikap peserta didik. "metode ini dapat menambah perkembangan pemahaman prosesproses ilmiah, pengetahuan berikut makna dari istilah-istilah, berpikir kritis dan bersikap positif' tambahnya.

Diri peserta didik ditanamkan dasa-dasar ilmiah melalui pembelajaran dengan pendekatan inquiry-discovery berupaya, selain itu juga agar kemampuan dan kreatifitas peserta didik berkembang terutama dalam hal memecahkan masalah yang mana mereka akan lebih banyak belajar sndiri (Sagala, 2004, p.53).Siswa benar-benar ditempatkan sebagai subjek yang belajar, dalam pendekatan ini pendidik hanya memiliki peran sebagai pembimbing dan fasilitator.Masalah yang ingin dipecahkan bisa saja bersumber dari pendidik atau peserta didik diberi keleluasaan untuk memilih masalahya sendiri.Kemudian selanjutanya pendidik bertugas menyediakan sumber yang bisa dijadikan sebagai rujukan belajar bagi peserta didik dalam rangka mempermudah peserta didik dalam memecahkan masalah, bimbingan, arahan dan pengawasan dari pendidik sangat besar pengaruhnya, tetapi intervensi terhadap kegiatan siswa dalam pemecaahan masalah harus dikurangi (Sagala, 2004, p.54).

Dalam mengaplikasikan

Pendekatan inquiry, maka harus 
memenuhi empat ciri atau kriteria, empat kriteria tersebut ialahkesesuaian, kerumitan, kejelasan, dan ketepatan. Peserta didik kemudian akan terlibat langsung kedalam pendekatan inquiry melalui 5 tahapan setelah guru mengajak peserta didik untukmenunjukan masalah yang akan dikaji yang sesuai dan cocok dengan materi bahan ajar yang akan diajarkan, siswa kelima tahap inquiry yaitu (Trianto, 2009, p.72):

a. Tahap siswa menentuhkan permasalahan yang menurut siswa terdapat tantangan sebagai bahan dalm penelitian.

b. Tahap siswa melakukan pengumpulan suatu data yang telah disepakati untuk menguji keadaan, masalah yang dihadapi, dan sifat khusus dari objek yang diteliti.

c. Tahap siswa mengumpulkan data yang telah disepakati untuk memisahkan variabel yang sesuai, memiliki hipotesisi, eksperimen untuk menguji hipotesis sehingga diperoleh hubungan sebab akibat.

d. Tahap merumuskan hasil penemuan melalui pendekatan inquiry hingga diperoleh prinsip yang lebih formal, pernyataan, danpenjelasan.

e. Tahap melakukan analisis terhadap proses inquiry, cara yang dilakukan oleh pendidik maupun siswa. Suatu analisis sangat diperlukan untuk membantu siswa lebih terarah dalam mencari sebab akibat.

Lima tahap di atas yang dijadikan sebagai salah satu upaya para pendidik di MI Islamiyah Butoh dalam pengoptimalisasian pembelajaran Akidah Akhla Kelas Empat, melalui kelima fase tersebut peserta didik dapat melakukan tugasnya sesuai dengan apa yang diharapkan oleh pendidik. Mulai dari pencarian masalah hingga proses analisis peserta didik dapat terlibat langsung, sehingga harapan pendidik akan pemahaman peserta didik mengenai materi secara mendetail cenderung menuai hasil yang maksimal.

Selanjutnya penggunaan pendekatan discovery dalam bebrapa keadaan tertentu sangat sesuai bagi kelaskelas rendah, dan sebaliknya pendekatan inquiry cocok bagi peserta didik yang berada dalam kelas yang lebih tinggi.Pendekatan discovery menekankan pada pendidik untuk membimbing dan memberikan arahan kepada peserta didik dan mendorong atau memberikan motivasi kepada pesert adidik untuk kemudian apat berfikit secara ilmiah, logis dan kritis. Tidak lain tujuannya adalaah supaya peserta didik mampu menemukan prinsip dasar dari pemasalahan yang dipecahkan, dan sampai sebarapa jauh peran pendidik bagi peningkatan kemampuan peserat didik.

Para pendidik dalam menggunakan pendekatan ini biasanya menggunaakan metode penugasan dan diskusi.Diskusi dilakukan setalah pembentukan keolompok kecil sekitar 3-5 orang untuk memecahkan permasalahan tetap dengan dengan arahan dan bimbingan langsung dari penddidik.Metode seperti ini dapat dilaukan pada saat kegiatan tatap muka dan bisa juga saat kegiatan terjadwal.Saat penerapan discovery pendidik hanya memberikan suatu permasalahan dan peserta didik diminta untuk memecahkan permasalahan melalui percobaan.Akan tetapi saat pendekatan inquiry, siswa dapat secara langsung mengajukan 
permasalahannya sendiri sesuai dengan pengarahan guru.Disinilah mental peserta didik dituntut untuk merancang dan melakukan percobaan, mengumpulkan dan menganalisis data, dan mengambil kesimpulan.

\section{SIMPULAN}

Optimalisasi

pembelajaran

memberikan pemahaman sesuai dengan aturan-aturan yang terdapat dalam pendekatan inquiry-discovery.Seorang pendidik selalu memiliki usaha lebih untuk bisa memberikan sebuah kesempatan kepada peserta didik agar dapat belajar melalui pemecahan atau penyelidikan terhadap suatu permasalahan.Layaknya problem solving, pemecahan masalah sebagai hal yang dipusatkan bagi peserta didik untuk mengasah keaktifannya melalui pendekatan inquiry secara mandiri.Peserta didik diberi peluang untuk mencari hingga menemukan sendiri solusi yang untuk memecahkan suatu permasalahan, dalam hal ini materi yang disajikan tidak dibahas sampai tuntas.Pondassi dasar pendekatan inquiry kuatnya ingatan peserta didik akan hasil belajar mereka melalui cara ini. Tidak hanya itu pendidikpun bisa lebih simple dan mudah dalam menyampaikan materi kepada peserta didik.Selain itu, materi juga menjadi lebih mudah untuk disampaikan kepada seluruh peserta didik.Penggunakan pendekatan inquiry-discovery pada mata pelajaran Akidah Akhlak kelas 4 ini mensyaratkan keterlibatan aktif peserta didik terbukti dengan meningkatnya pemahaman, prestasi belajar, serta sikap peserta didik.

Lima tahap yang dijadikan sebagai upaya para pendidik di MI Islamiyah Butoh dalam pengoptimalisasian pembelajaran Akidah Akhla Kelas Empat yaitu (a) Tahap siswa menentuhkan permasalahan yang menurut siswa terdapat tantangan sebagai bahan dalm penelitian.
Tahap siswa melakukan pengumpulan suatu data yang telah disepakati untuk menguji keadaan, masalah yang dihadapi, dan sifat khusus dari objek yang diteliti. (c) Tahap siswa mengumpulkan data yang telah disepakati untuk memisahkan variabel yang sesuai, memiliki hipotesisi, eksperimen untuk menguji hipotesis sehingga diperoleh hubungan sebab akibat. (d) Tahap merumuskan hasil penemuan melalui pendekatan inquiry hingga diperoleh prinsip yang lebih formal, pernyataan, dan penjelasan. (e) Tahap melakukan analisis terhadap proses inquiry, cara yang dilakukan oleh pendidik maupun siswa. Suatu analisis sangat diperlukan untuk membantu siswa lebih terarah dalam mencari sebab akibat.

\section{DAFTAR PUSTAKA}

Ahmatika, Deti. (2016). Peningkatan Kemampuan Berpikir Kritis Siswa Dengan Pendekatan Inquiry/Discovery.Jurnal Euclid,03(1). 398

Azhar, Khoirul dan Izzah Sa'idah.(2017). Studi Analisis Upaya Guru Akidah Akhlak dalam Mengembangkan Potensi Nilai Moral Peserta Didik di MI Kabupaten Demak.Jurnal Ta'dib, 10 (2). 78

Depdikbud.(1995). Kamus Besar Bahasa Indonesia.Jakarta: Balai Pustaka.

Dewi, Ni Putu Laksmi Cintya. (2017). The effect of application of contextual teaching and learning (CTL) model-based on lesson study with mind mapping media to assess 
student learning outcomes on chemistry on colloid systems.International Journal of Science and Applied Science: Conference Series. 01 (02). Yogyakarta. 168

Kriyantono, Rachmat. (2017). Teknik Praktik Riset Komunikasi.Jakarta: Prenada Media.

Mawardi, Komparasi Model Pembelajaran Discovery Learning dan Problem Solving Ditinjau dari Hasil Belajar IPA pada Siswa Kelas 3 SD di Gugus Diponegoro Tengaran" dalam SCHOLARI: Jurnal Pendidikan dan Kebudayaan. 06 (01).Tanggerang. 128

Sagala, Syaiful. (2004). Konsep dan Makna Pembelajaran.Bandung: Penerbit Alfabeta.
Sagala, Syaiful. (2010). Supervisi Pembelajaran dalam Profesi Pendidikan. Bandung: Alfabeta.

Sudjana, Nana.(2005).Dasar-dasar/ Proses Belajar Mengajar.Bandung: Sinar Baru Algensindo.

Trianto.(2009).Mendesain Model Pembelajaan Inovatif

Progresif.Surabaya:Kencan 